\title{
Use of Google Earth in biosecurity: moth trapping in California
}

\author{
T.E.S. Sullivan ${ }^{1}$, L.D. Stringer ${ }^{1}$, G.S. Simmons ${ }^{2}$, K. Harding ${ }^{2}$ and D.M. Suckling ${ }^{1}$ \\ ${ }^{1}$ The New Zealand Institute for Plant E Food Research Limited (Plant E Food Research), \\ Private Bag 4704, Christchurch, New Zealand \\ ${ }^{2}$ USDA APHIS PPQ CPHST, Moss Landing, California, USA \\ Corresponding author:Thomas.Sullivan@plantandfood.co.nz
}

Geographic Information Systems (GIS) have been used during major invasive insect incursion responses in New Zealand since about 1999. The exchange of local mapping software enabled sharing of data that could be reviewed and analysed by researchers and programme response personnel across the country to help develop invasive species control and response plans quickly. Two examples include the New Zealand response to the Argentine ant and painted apple moth invasions. Advances in web services have globalised delivery of information, and Google Earth in particular has offered novel value that has been explored with co-operators in USDA. Here, data were converted from a excel spreadsheet to ${ }^{\star} . \mathrm{kml}$ format, plotted in various pre-determined ways and saved as $\mathrm{a}^{\star} \cdot \mathrm{kmz}$ file that could be emailed. Lower than desired analytical functionality was met by better forward planning of analyses for mapping. The population expansion of the light brown apple moth in California is offered as a case study to indicate how rapidly evolving tools can help surveillance programmes, and contrasts with earlier surveillance information management methods used in New Zealand.

\section{Plant-back safety of fodder beet (Beta vulgaris) following the application of tribenuron-methyl}

\author{
C. Dowsett, T.K. James and A. Rahman \\ AgResearch, Ruakura Research Centre, Private Bag 3123, Hamilton 3240 \\ Corresponding author: claire.dowsett@agresearch.co.nz
}

Tribenuron-methyl is a sulfonylurea herbicide for control of certain broadleaf weeds in cereal crops and prior to conservation tillage. Safe plant-back periods for this herbicide are expected to be shorter in acid soils compared to neutral or alkaline soils due to a faster rate of degradation at low $\mathrm{pH}$ levels. This research was conducted to determine the safe plant-back period for fodder beet following use of tribenuron-methyl in New Zealand soils. Two similar sedimentary soils from Hawke's Bay were used in this glasshouse study, one with a $\mathrm{pH}$ of 7.0 and the other with a $\mathrm{pH}$ of 5.5. Residual activity of the herbicide was measured by bioassay using fodder beet as the test species. The plant-back times were 14, 28, 42 or 56 days after spraying. Assessments included number of plants emerged, plant vigour scores and dry matter weights 8 weeks after planting. The results showed that in the low $\mathrm{pH}$ soil a plant-back period of 14 days is sufficient, although the best growth and vigour was noted if planting was carried out 28 days after spraying. In the high $\mathrm{pH}$ soil even the longest period of 56 days tested in this study was not safe for planting of fodder beet. 